\title{
Tracheria Troyana (Krapovickas and Nasif, 2011): Redefinition, Environmental Distribution, and Heritage Conservation
}

\author{
Verónica Krapovickas ${ }^{a}$, Nahuel A. Muñoz ${ }^{b}$, Pablo Alonso Muruaga ${ }^{c}$, Patricia L. Cicciolic, Sergio Marenssi ${ }^{c}$, \\ and Sergio F. Vizcaíno ${ }^{b}$ \\ ${ }^{a}$ IDEAN-CONICET, Department of Geological Sciences, FCEN, Buenos Aires University, Argentina; ${ }^{b}$ CONICET, Vertebrate Paleontology Division, \\ La Plata Museum, Anexo, La Plata, Argentina; 'IGEBA-CONICET, Department of Geological Sciences, FCEN, Buenos Aires University, Argentina
}

\begin{abstract}
The South American caviomorph ichnogenus Tracheria troyana is reevaluated here based on recently discovered specimens that allow a more thorough investigation of footprint taphonomy and ichnotaxonomy. The footprints include detailed autopodium morphology and more complete gait patterns than previously reported. The redefinition of $T$. troyana involves key aspects as digit impressions of the manus asymmetrically arranged and digit $\mathrm{V}$ being the shortest and at times do not print. It generally lacks metacarpal pads, resulting in almost digitigrade impressions and regularly preserved as tridactyl footprints. In the pes imprints, digits have a symmetrical arrangement. Phalangeal and metapodial pad impressions are preserved, occasionally showing the presence of two heel pads. Trackways denote a marked overstep in which the pes impressions are placed in front of the manus. New data about $T$. troyana environmental distribution shows that typically characterizes overbank facies of anastomosing and meandering fluvial systems, which may be reflecting a habitat preference the producer. Here, we also present new digitized 3D images of the original type material of $T$. troyana, in order to preserve these materials, which were previously only available for viewing in the field.
\end{abstract}

\section{KEYWORDS}

3D modeling; Vinchina Formation; Miocene; Fluvial setting; Dinomyid caviomorph footprints

\section{Introduction}

The Pacarana (Dinomys branickii Peters, 1873) is the only living species of an almost relictual family of hystricognath rodents (Dinomydae) that was diverse and widely distributed during the Miocene-Pliocene (3-23 Ma before present) (Nasif, 2010). The dinomyids are a monophyletic group endemic to South America, which live today in forested areas of the eastern Andes (White and Alberico, 1992). Large dinomyid footprints (Tracheria troyana Krapovickas and Nasif 2011) have been investigated over the last five years in the Vinchina Formation (Miocene), La Rioja Province, Argentina, together with other fossil footprints (Krapovickas and Nasif, 2011; Krapovickas and Vizcaíno, 2016). The outstanding record of the Vinchina Formation includes exceptionally preserved and plentiful footprints and trackways, most of which have no analogues in extant faunas. They comprise footprints of (1) ground sloths (Venatoripes riojanus Frenguelli 1950 and other kidney-like footprints); (2) small tridactyl footprints of a homopod rodent-like mammal possibly a caviomorph rodent or typothere notoungulate; (3) Macrauchenichnus isp., which is interpreted as toxodontid notoungulates or macraucheniid litopterns; (4) large tridactyl footprints of rheiformes; (5) footprints of shorebirds assigned to Gruipeda isp.; and (6) a small tridactyl to tetradactyl footprint with pronounced scratch marks (Krapovickas et al., 2009a; Krapovickas et al., 2009b; Krapovickas et al., 2013).

The people of the town of Vinchina, located $2 \mathrm{~km}$ from the outcrops, are well aware of the paleontological heritage preserved at the surrounding of their home town. The holotype material of Tracheria troyana represents a unique example of community concern about paleontological heritage. The footprints were named "the hands" by the local people (Krapovickas and Nasif, 2011), who attempted to preserve the fossil footprints when they were about to be damaged during explosions planned during repairs of the mountain road (R76) that crosses the outcrop. Although the demolition did not occur, the rocks containing the specimens were extracted. A series of misunderstandings between the local and

CONTACT Verónica Krapovickas vkrapovickas@gl.fcen.uba.ar @ Departamento de Cs. Geologicas, FCEN, Universidad de Buenos Aires, Intendente Güiraldes 2160, Ciudad Universitaria C1428EGA, Argentina. 

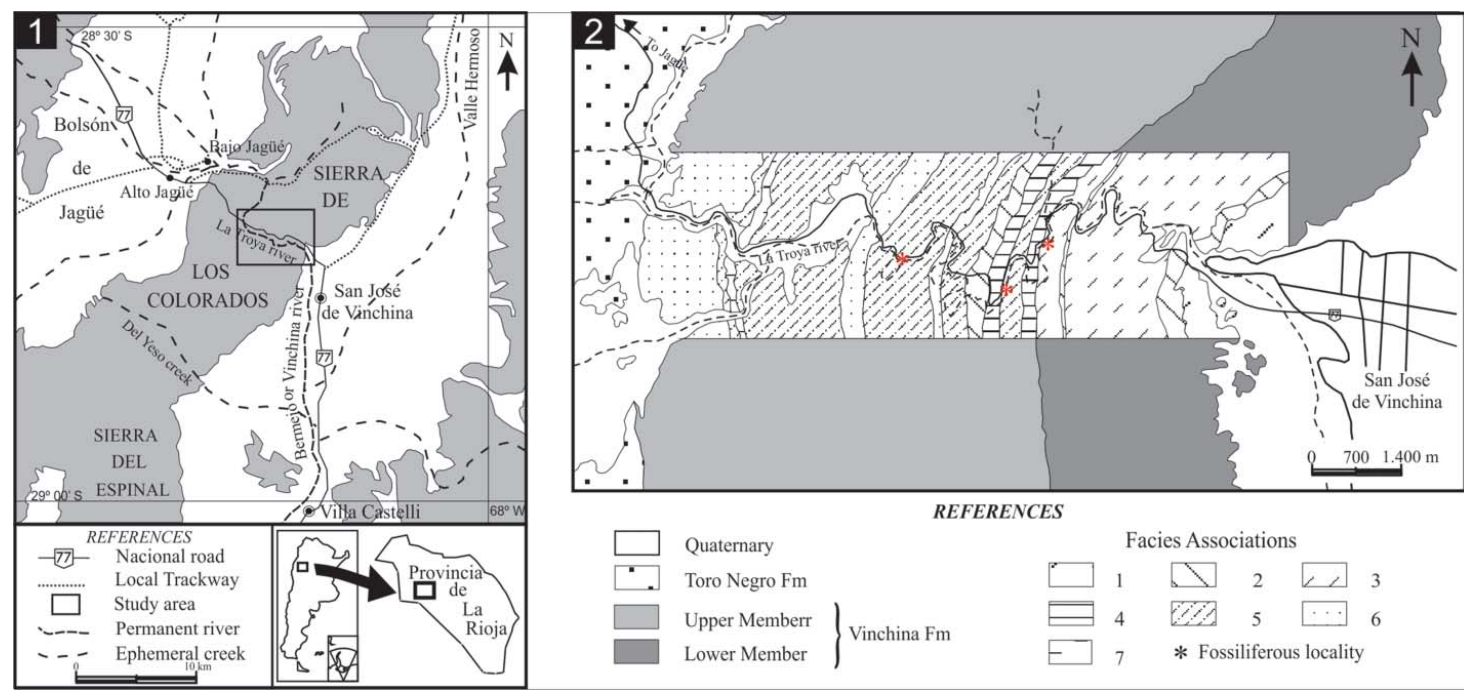

Figure 1. 1) Location map. 2) Facies map of the study area, indicating the occurrences of Tracheria troyana.

provincial authorities ended with both the paleontologists that did the extraction and the footprints at the police station (El Independiente, La Rioja, October 24, 2007). Eventually the paleontologists were freed, but the footprints remained under the custody of the police officers. The lack of a local museum that could ensure the proper preservation of the material, together with the strong interest of the inhabitants of Vinchina to keep their historical heritage nearby where "it belongs" precluded the material to be properly housed. To date, the holotype, paratype, and other examples of Tracheria troyana are still housed at the police station.

We performed a 3D scan of the material housed at the police station in order to accurately document the material in danger. Photographs alone are insufficient to protect the paleontological heritage of this region. It is necessary to protect the material that remains in situ by means of some legal form (i.e., protected area, natural reserve), and in addition to safeguard as much information as we can. The aim of this contribution is to record new material of Tracheria troyana, redefine the ichnogenus based on new evidence, digitally preserve the paleontological heritage through 3D modeling techniques, investigate the morpho-functional aspects expressed in T. troyana, and finally, discuss the paleoenvironmental distribution of these footprints.

\section{Geological setting}

The Miocene Vinchina Formation (Turner, 1964) is one of the thickest sedimentary units related to the Andean Orogeny in Argentina, reaching more than 5,100 meters in its type section. It forms the bulk of the Sierra de Los Colorados, La Rioja Province, NW Argentina (Fig. 1), and records the main infill stage of the Vinchina Basin in the broken foreland of western Argentina. The Vinchina Formation rests on a low-relief erosive surface over the eolian sandstones of the early Miocene (?) Vallecito Formation (Tripaldi, 2002; Ciccioli et al., 2010; Ciccioli et al., 2011; Ciccioli et al., 2013), and it is unconformably covered by alluvial sandstones, mudstones, and conglomerates of the Late Miocene-Pliocene Toro Negro Formation (Turner, 1964; Ramos, 1970; Ciccioli et al., 2010; Amidon et al., 2016).

The Vinchina Formation consists of sandstones, mudstones, and conglomerates that accumulated mainly in fluvial and lacustrine environments under arid to semiarid conditions, with minor intercalations of eolian deposits (Fig. 2) (Tripaldi et al., 2001; Ciccioli et al., 2013; Marenssi et al., 2015). Ramos (1970) divided this unit in two members. The Lower Member is characterized by mudstones and arkosic sandstones with highly altered volcanic rock fragments. The Upper Member is composed of muddy sandstones with intercalations of tuffaceous sandstones and conglomerates that contain both fresh and altered volcanic clasts. At the locality of La Troya Creek, the contact between the Lower and Upper members is marked by progressive unconformities that are draped by several conglomerate horizons (Marenssi et al., 2000).

Detailed sedimentological descriptions and facies analyses of the Vinchina Formation along the Sierra de Los Colorados (Tripaldi et al., 2001; Ciccioli et al., 2013) were used to propose that both basement and foldthrust-belt tectonics controlled the development of several sedimentation cycles, which are interpreted as third-order alluvial sequences (Marenssi et al., 2015). Advance of the fold-and-thrust belt (Precordillera) from the west and simultaneous basement uplift to the north 

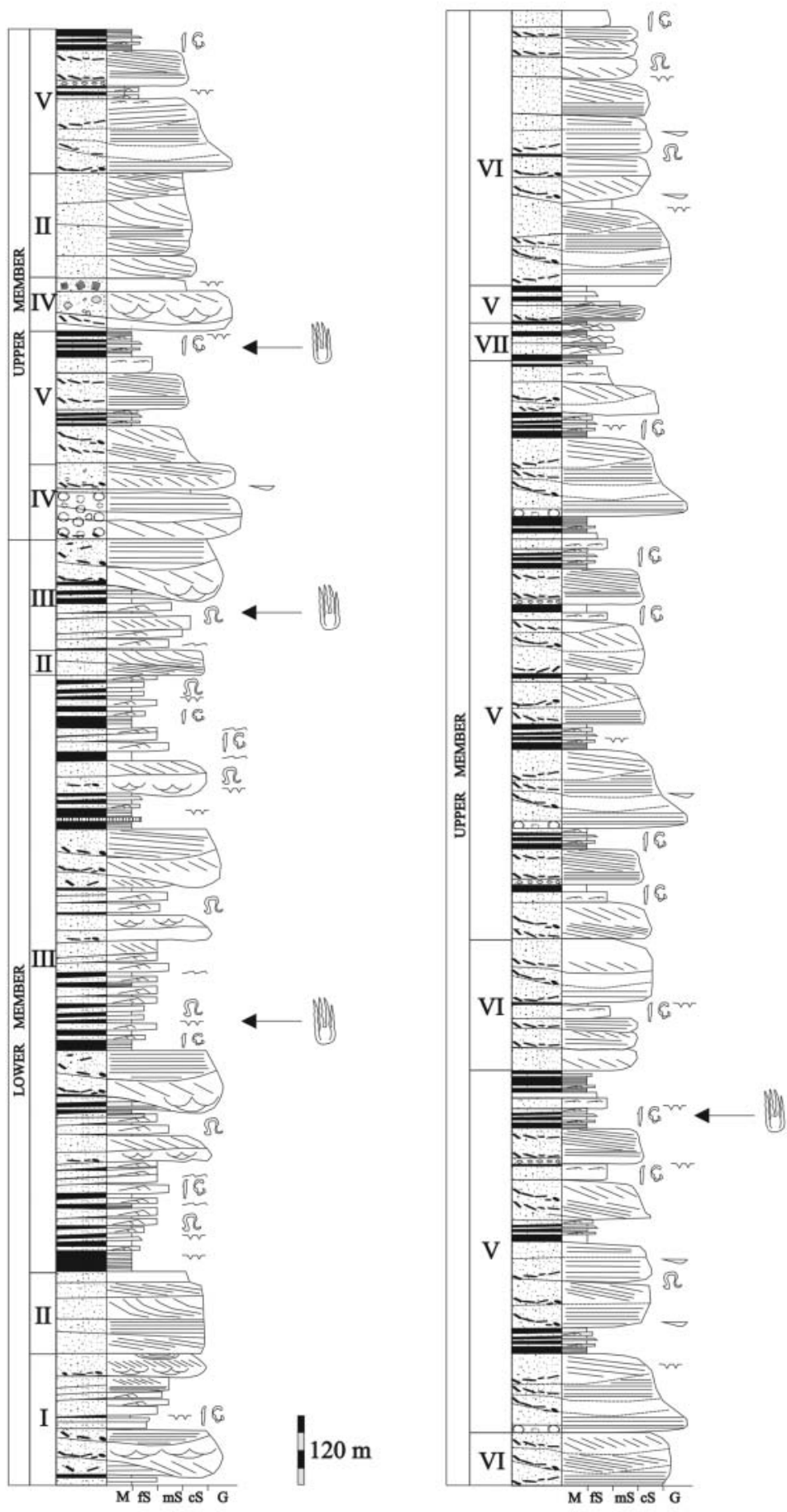

\begin{tabular}{|c|c|}
\hline & REFERENCES \\
\hline :8:80 & Conglomerates \\
\hline $0: 0$ & Gravely sandstone \\
\hline & Sandstone \\
\hline 【 & Tuff \\
\hline & Mudstone \\
\hline & Horizontal lamination \\
\hline$\cong$ & Low-angle cross bedding \\
\hline$x>$ & Planar cross bedding \\
\hline & Trough cross bedding \\
\hline & Ripple cross lamination \\
\hline 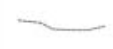 & Amalgamation surfaces \\
\hline$\infty$ & Sole marks \\
\hline$\sim$ & Current ripples \\
\hline 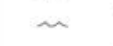 & Wave ripples \\
\hline$m$ & Desiccation cracks \\
\hline$\Omega$ & Convolute bedding \\
\hline 16 & Bioturbation \\
\hline$\rightarrow$ & Sand clasts \\
\hline & Mud clasts \\
\hline (1) & Tracheria troyana \\
\hline I-VII & Facies association \\
\hline
\end{tabular}

Figure 2. Vertical profiles of the Vinchina Formation. The occurrences of Tracheria troyana are indicated in the related facies through the section (Modified from Tripaldi et al., 2001).

(Sierra de Toro Negro) controlled subsidence as well as drainage patterns. Consequently, the Lower Member of the Vinchina Formation records sedimentation in a more distal position than the Upper Member relative to the fold-and-thrust belt, and at the same time, both members record a proximal (north) to distal (south) trend with respect to the elevated basement-cored block.
Recently obtained high-precision $\mathrm{U}-\mathrm{Pb}$ dates on volcanic zircons estimate the bulk of the Vinchina Formation to span roughly 15.6-9.2 Ma (Ciccioli et al., 2014), although new data from the overlying Toro Negro Formation suggest that the actual duration of the sedimentation along the La Troya Creek section was significantly longer, perhaps reaching up to the $8.2 \mathrm{Ma}$ (Amidon et al., 2016). 
Table 1. Lithofacies types and codes modified from Miall (2010).

\begin{tabular}{|c|c|c|}
\hline $\begin{array}{l}\text { Facies } \\
\text { Code }\end{array}$ & Facies Description & Interpretation \\
\hline Gmi & $\begin{array}{l}\text { Massive intraformational } \\
\text { conglomerates }\end{array}$ & $\begin{array}{l}\text { Lag deposits, longitudinal } \\
\text { bars }\end{array}$ \\
\hline Gp & $\begin{array}{l}\text { Planar cross-bedded } \\
\text { conglomerates }\end{array}$ & Transverse bedforms \\
\hline Gh & $\begin{array}{l}\text { Clast-supported horizontally } \\
\text { stratified cross conglomerates }\end{array}$ & $\begin{array}{r}\text { Longitudinal bedforms, lag } \\
\text { deposits, sieve deposits }\end{array}$ \\
\hline SGp & $\begin{array}{l}\text { Planar cross-bedded gravelly } \\
\text { sandstone }\end{array}$ & $\begin{array}{l}\text { Transverse and linguoid } \\
\text { gravelly sand bedforms, } \\
\text { (2-D) dunes and bars. }\end{array}$ \\
\hline Sp & Planar cross-bedded sandstone & $\begin{array}{l}\text { Transverse and linguoid } \\
\text { bedforms (2-D) dunes }\end{array}$ \\
\hline St & Trough cross-bedded sandstone & $\begin{array}{l}\text { Sinous crested and linguoid } \\
\text { (3-D) dunes }\end{array}$ \\
\hline Sh & Horizontally bedded sandstone & $\begin{array}{l}\text { Plane bed flow (critical } \\
\text { flow) }\end{array}$ \\
\hline Sm & Massive sandstone & $\begin{array}{l}\text { Sediment gravity flow } \\
\text { deposits }\end{array}$ \\
\hline $\mathrm{Sr}$ & $\begin{array}{l}\text { Ripple cross-Laminated } \\
\text { sandstone }\end{array}$ & Ripples (lower flow regime) \\
\hline $\mathrm{Fr}$ & $\begin{array}{l}\text { Ripple cross-Laminated } \\
\text { mudstone }\end{array}$ & Ripples (lower flow regime) \\
\hline $\mathrm{Fl}$ & Laminated mudstone & $\begin{array}{l}\text { Overbank, abandoned } \\
\text { channel. Or waning } \\
\text { flood deposits }\end{array}$ \\
\hline $\mathrm{Fm}$ & Massive mudstone & $\begin{array}{l}\text { Overbank, abandoned } \\
\text { channel. Or drape } \\
\text { deposits }\end{array}$ \\
\hline
\end{tabular}

\section{Tracheria troyana-bearing strata}

Descriptions of the facies and the new tetrapod traces are provided below (Figs. 1 and 2). The lithofacies classification used was modified from Miall (2010; Table 1). Fluvial architectural elements identified (sensu Miall, 1996) including composite (multistory) channel fills (element $\mathrm{CHm}$ ), isolated (single) channel fills (CHs), gravel bars (element $\mathrm{GB}$ ), down-stream accretion macroforms (DA), lateral-accretion macroforms (LA), sandy macroforms (SB), laminated sand sheets (LS), crevasse channels (CR), crevasse splays (CS), and floodplain deposits (OF) are used following Marenssi, et al. (2015).

\section{Facies A: Anastomosing fluvial deposits}

\section{Facies description}

This facies is characterized by multistory composite channel deposits $(\mathrm{CHm})$, consisting of coarse- and medium-grained sandstone bodies that form channel belts (5-10 $\mathrm{m}$ thick) separated by thick intervals of fine-grained sediments (OF). Channel belts are bounded by a flat or slightly concave-upward erosional surfaces (5th-order surface in the sense of Miall, 1995). Each stratal unit is bounded by 4thorder or 3th-order surfaces that are commonly floored by a thin lag of massive intraformational conglomerates $(\mathrm{Gmi})$ and/or massive gravelly sandstones
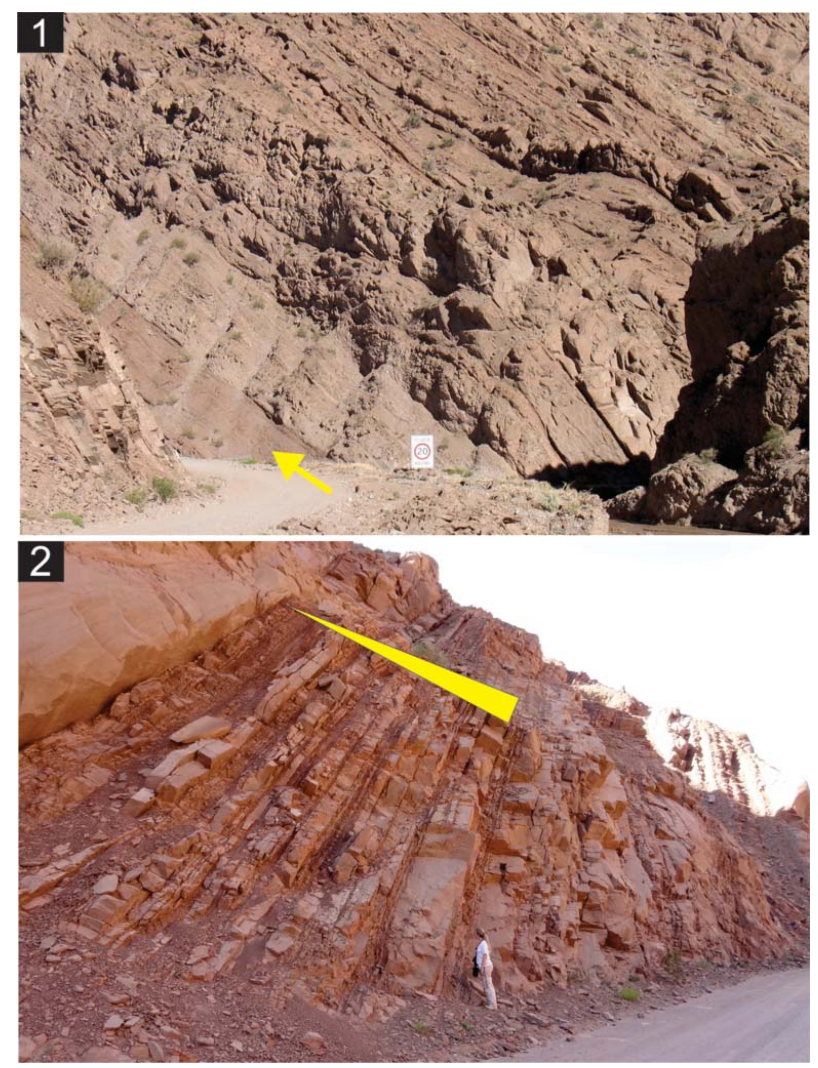

Figure 3. Outcrop-scale view of 1.) red-colored floodplain finegrained sediments (yellow arrow) of an anastomosing fluvial system grading upward into braided fluvial deposits and 2.) Meandering fluvial system deposits (F2). Note the sandstones interbedded with mudstones displaying a general fining-upward trend.

(SGm). These conglomerates are covered by mediumto large-scale sets of coarse- to medium-grained cross-bedded sandstones (St, Sp) deposited by downstream migration of transverse channel bars (DA). Horizontally laminated and ripple cross-laminated fine-grained sandstones (Sh, Sr) occur at the top of the succession as longitudinal sandy bars (SB). The interchannel areas contain single-story (or rarely twostory) channels (CR) usually less than $1.5 \mathrm{~m}$ thick (Fig. 3.1). These channels have planar, erosional bases and are composed of massive coarse-grained sandstones, large-scale sets of trough cross-bedded coarsegrained sandstones (St), and scarce intraformational conglomerates $(\mathrm{Gi})$, which contain extraformational granules and pebbles. Ripple cross-laminated finegrained sandstones $(\mathrm{Sr})$ and thin beds of massive mudstones (Fm) appear at the tops of these channels. Thin, sharp-based tabular beds (CS) adjacent to the channels contain massive $(\mathrm{Sm})$, horizontally laminated (Sh), or ripple cross-laminated (Sr) fine- and medium-grained sandstones with interbedded massive mudstones (Fm). Muddy flood-basin deposits (OF) 
Table 2. Summary of the main characteristics of the fluvial deposits bearing Tracheria troyana in the Vinchina Formation. Less frequent architectural elements and lithofacies are shown in parentheses (modified from Marenssi et al., 2015).

\begin{tabular}{|c|c|c|c|}
\hline Facies & Lithofacies & $\begin{array}{l}\text { Architectural } \\
\text { Elements }\end{array}$ & $\begin{array}{l}\text { Interpretation of the Fluvial } \\
\text { System }\end{array}$ \\
\hline A & $\begin{array}{l}\text { Sp, St, Sh, (Gmi) } \\
\text { Sr, Fm, Fl, Sm }\end{array}$ & $\begin{array}{c}\mathrm{CHm},(\mathrm{DA}, \mathrm{SB}) \\
\mathrm{OF}, \mathrm{CS}, \mathrm{CR}\end{array}$ & $\begin{array}{l}\text { Anastomosed (either with } \\
\text { mixed sand-mud } \\
\text { floodplains or with mud- } \\
\text { dominated floodplains) }\end{array}$ \\
\hline B & $\begin{array}{l}\text { SGp, Sp, Sr, Gm, } \\
(\mathrm{Gp}, \mathrm{Gh}) \mathrm{Fr}, \mathrm{Fm}\end{array}$ & CHs, LA, (GB) & $\begin{array}{l}\text { Heterolithic high-sinuosity } \\
\text { (meandering) }\end{array}$ \\
\hline
\end{tabular}

are mainly composed of up to 2-m-thick intervals of red massive $(\mathrm{Fm})$ or laminated mudstones $(\mathrm{Fl})$. Scarce intercalations of red massive $(\mathrm{Sm})$ or ripple crosslaminated fine-grained sandstones (Sr), up to $1 \mathrm{~m}$ thick, are present within the sandy flood basin deposits. Desiccation cracks and carbonate nodules are common features of the flood-basin sediments. In some cases, floodplain deposits form coarseningupward and thickening-upward successions up to $12 \mathrm{~m}$ thick.

\section{Interpretation}

These fluvial deposits are interpreted as an anastomosed fluvial system with mixed sand-mud floodplains, due to the presence of thick multistory channel belts $(\mathrm{CHm})$ encased within flood-plain deposits that include stacked coarsening-upward crevasse splays (CS, CR) and muddy flood-basin (OF) deposits (Table 2) (Limarino et al., 2001; Tripaldi et al., 2001; Marenssi et al., 2015).

\section{Ichnology}

Fossil tetrapod footprints were found in sandstones interbedded with mudstones beds that represent floodplain deposits. Two main assemblages were recognized. One (A1) occurs on a big fallen block and consists of four trackways preserved as positive hyporelief (Fig. 4.1). They all show tetradactyl manus and pes impressions of sub-equal size with long and robust digits with strong elongated claws. The manus average length is $76 \mathrm{~mm}$ and average width is $56 \mathrm{~mm}$, while the pes average length is $85 \mathrm{~mm}$ and average width is $49 \mathrm{~mm}$. Manus imprints are asymmetrical; digit III is the longest, digits II and IV are shorter and sub-equal, and digit $\mathrm{V}$ is the shortest and

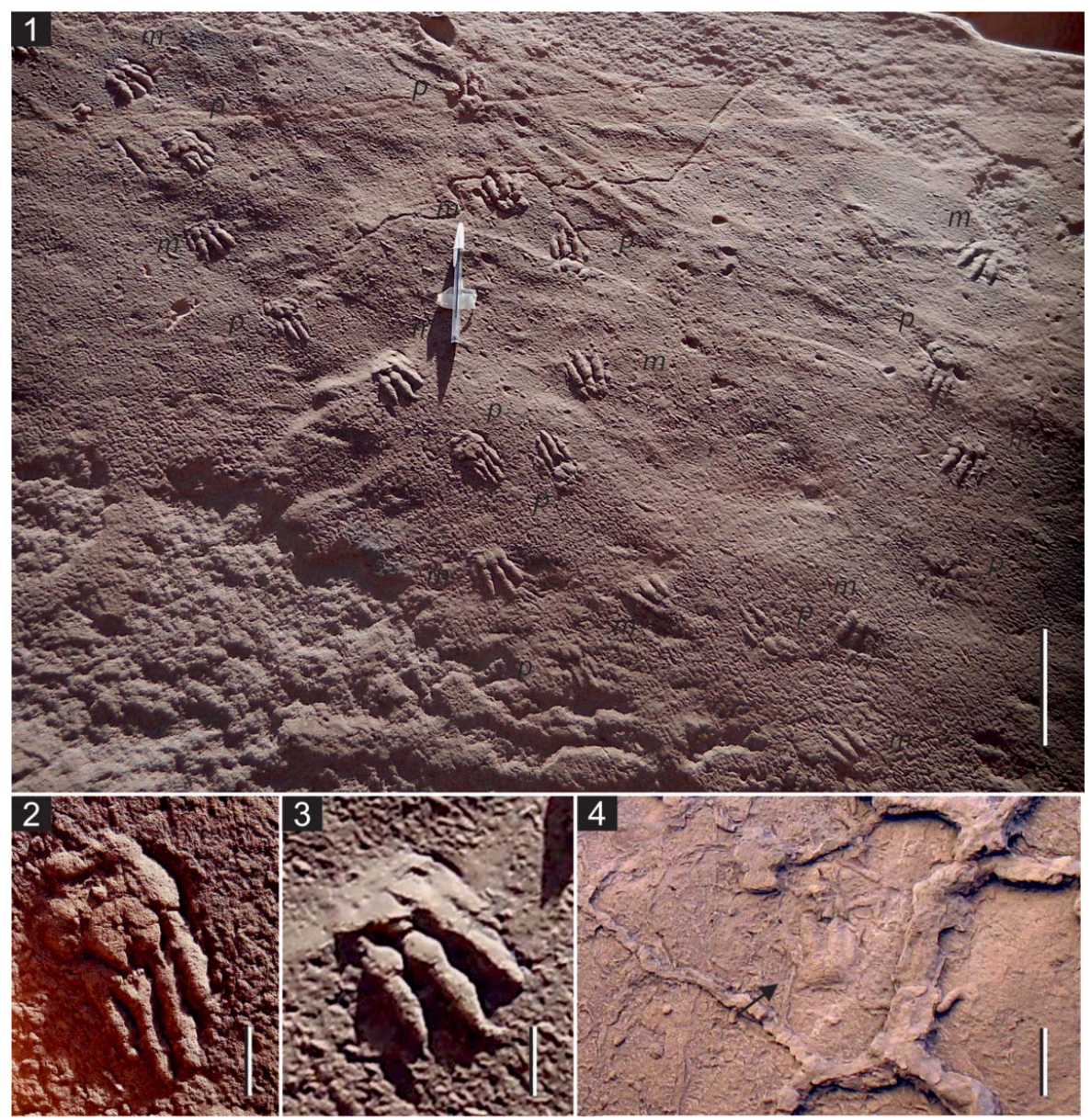

Figure 4. New footprints preserved at the localities 1 and 3. 1.) Trackways preserved at locality 1 (A1). Scale bar is $15 \mathrm{~cm}$. 2 .) Pes imprint. Scale bar is $2 \mathrm{~cm}$. 3.) Manus imprint. Scale bar is $2 \mathrm{~cm}$. 4.) Isolated tetradactyl footprint (arrow) of locality 3 (B1). Scale bar is $8 \mathrm{~cm}$. 


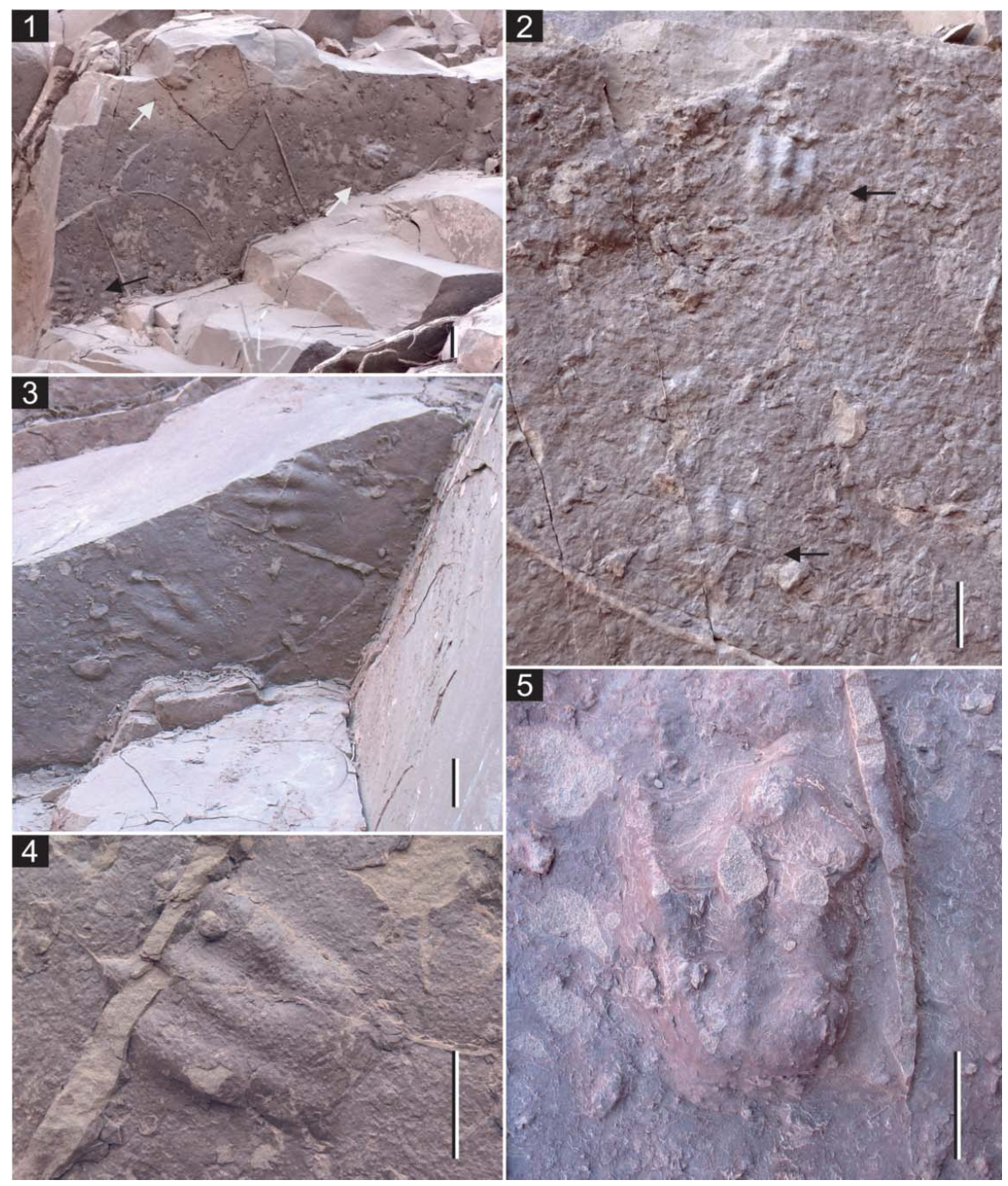

Figure 5. New footprints preserved at the localities 2 and 4. 1-4. Footprints recorded at locality 2 (A2). 1. Isolated tridactyl footprint (black arrow) and tetradactyl footprints (grey arrow). Scale bar is $6 \mathrm{~cm}$. 2. Two consecutive tridactyl footprints. Scale bar is $6 \mathrm{~cm}$. 3 . Set of tetradactyl plantigrade and tridactyl footprints. Scale bar is $6 \mathrm{~cm}$. 4. Isolated tridactyl imprints recorded. Scale bar is $4 \mathrm{~cm}$. 5 . Isolated tridactyl imprints recorded at locality 4 (B2). Scale bar is $3 \mathrm{~cm}$.

at times are not impressed (or preserved). Manus digit prints are more robust than the pes impressions (average manus digital width is $12 \mathrm{~mm}$; average pes digital width is $9 \mathrm{~mm}$ ), and show major inter-digital divarication angles than the pes impressions (Fig. 4.3). In the best preserved impressions, the manus impressions demonstrate well developed phalangeal pads, but lacks metacarpal pads. The pes impressions are more slender than in the manus impression and are symmetrical and tetradactyl, with the central digits (III-IV) longer than the lateral digits (II-V) (Fig. 4.2). Elongated metatarsal pad impressions are present behind all digit impressions, and tarsal pad impressions are preserved when the imprints are fully plantigrade. The central metatarsal pad impressions (III-IV) are slightly further forward than the lateral ones.

Trackways are narrow and footprint impressions lie near to the midline. The pes impressions are in front of, and more lateral to the midline, than the manus impressions. Finally, the pes footprints are plantigrade and manus footprints are more digitigrade. No other footprint type has been found in this surface.

The second assemblage (A2) is characterized by two consecutive tridactyl footprints, a set of a tetradactyl and a tridactyl imprint and two isolated tridactyl imprints (Fig. 5.1-4) preserved in positive hyporelief. The first set shows three long and robust digits of sub-equal size with prominent claw impressions. The manus imprints have paralleled digits while the pes digit impressions are more separated and, consequently, with a greater divarication angle (Fig. 5.2). Imprints with parallel digits are approximately $9 \mathrm{~cm}$ long and $6 \mathrm{~cm}$ wide, whereas the impressions showing greater divarication are $6 \mathrm{~cm}$ long and $8 \mathrm{~cm}$ wide. The second track set is a tetradactyl and a tridactyl footprint (Fig. 5.3). The tetradactyl impression is 
plantigrade with long and robust digits and metapodial pad impressions. Lateral digits impressions are shorter than central ones. In the tridactyl footprint, digit III is the longest while digits II and IV are shorter. The third track set are tetradactyl imprints preserved as two consecutive imprints of $8 \mathrm{~cm}$ long and $5 \mathrm{~cm}$ wide (Fig. 5.1). In this set, the digit III imprint is the longest, digits II and IV are shorter, and digit V is the shortest. Digits are wide, highly connected with each other, and lack of phalangeal pad impressions. Other footprints of the same assemblage are: Macrauchenichnus rector Angulo \& Casamiquela 1982, interpreted as produced by mediumsized macraucheniid litopterns. Macrauchenichnus isp. is interpreted to have been produced by toxodontid notoungulates or macraucheniid litopterns (Krapovickas and Vizcaíno, 2016).

\section{Facies B: Meandering river deposits}

\section{Facies description}

This facies is composed of tabular to lensoid bodies (CHs) of sandstones up to $3 \mathrm{~m}$ thick separated by massive mudstones $(\mathrm{OF})$, forming upward-fining deposits. Channel (CHs) deposits are characterized by coarse- to medium-grained sandstone bodies (1-3 m thick) with low-relief erosional bases (5th-order surfaces of Miall, 1995) overlain by decimeter-thick beds of massive extraformational and intraformational conglomerates $(\mathrm{Gm})$. The sandy interval is made up mostly of large-scale, cross-bedded sets of coarse-grained to pebbly sandstones (Sp, SGp). These sets are bounded by inclined 4th-order surfaces (Miall, 1995) that indicate lateral migration of the channels (LA). Ripple cross-laminated fine-grained sandstones $(\mathrm{Sr})$ and massive sandstones $(\mathrm{Sm})$ are frequently found at the top of the channel deposits. Floodplain sediments $(\mathrm{OF})$ are 0.5 to $2 \mathrm{~m}$ thick, comprising ripple cross-laminated ( $\mathrm{Fr}$ ) and massive red mudstones (Fm) with desiccation cracks, and in some cases, very thin gypsum laminae (Fig. 3.2). Massive mudstones are bioturbated, exhibiting vertebrate and invertebrate trace fossils assemblages.

\section{Interpretation}

This facies is interpreted as a transition from a heterolithic high-sinuosity (meandering) to low-sinuosity (wandering) fluvial system. This interpretation is based on the presence of upward-fining deposits made up of tabular beds of sandstones, with lateral-accretion-dominated macroforms (LA) and massive mudstones deposited in floodplain areas (OF) (Table 2) (Miall, 1996; Tripaldi et al., 2001; Ciccioli et al., 2013; Marenssi et al., 2015).

\section{Ichnology}

Fossil tetrapod footprints were found in mudstones representing floodplain deposits. Two main assemblages were recognized. The first assemblage (B1) records one isolated tetradactyl plantigrade impression with long and robust digits and metapodial pad impressions, assignable to T. troyana (Fig. 4.4). Lateral digits impressions are shorter than medial digits, although one of these is slightly shorter than the other. Additional tetrapod tracks found in the assemblage correspond to small tridactyl footprints of a homopod rodent-like mammal, possibly a caviomorph rodent or typothere notoungulate. Macrauchenichnus isp. interpreted as toxodontid notoungulates or macraucheniid litopterns; large tridactyl footprints of rheiformes; footprints of shorebirds assigned to Gruipeda isp.; and a small tridactyl to tetradactyl footprint with pronounced scratch marks (Krapovickas et al., 2009a; Krapovickas et al., 2009b; Krapovickas and Vizcaíno, 2016).

The second assemblage (B2) records one isolated tetradactyl plantigrade mold with long and robust digits and metapodial pad impressions, putatively assignable to T. troyana (Fig. 5.5). Lateral digits are shorter than central digits, one of these is slightly shorter that the other. There are other ichnological morphotypes, such as Venatoripes riojanus, which are interpreted as large sloth footprints; kidney-like footprints possibly produced by a medium to small sloth; and large shorebird tetradactyl footprints.

\section{Digital models}

Three specimens of T. troyana housed at the police station of Vinchina Town were digitized using a NextEngine Desktop 3D Scanner (Fig. 6) and surface meshes

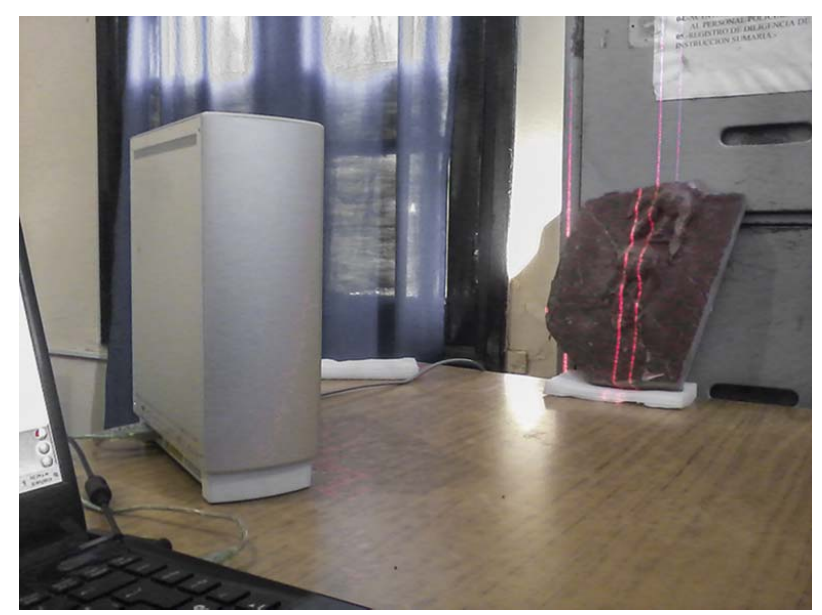

Figure 6. Manus-pes set F2 from Trackway 2 (see Krapovickas and Nasif, 2011) being scanned at the police station. 

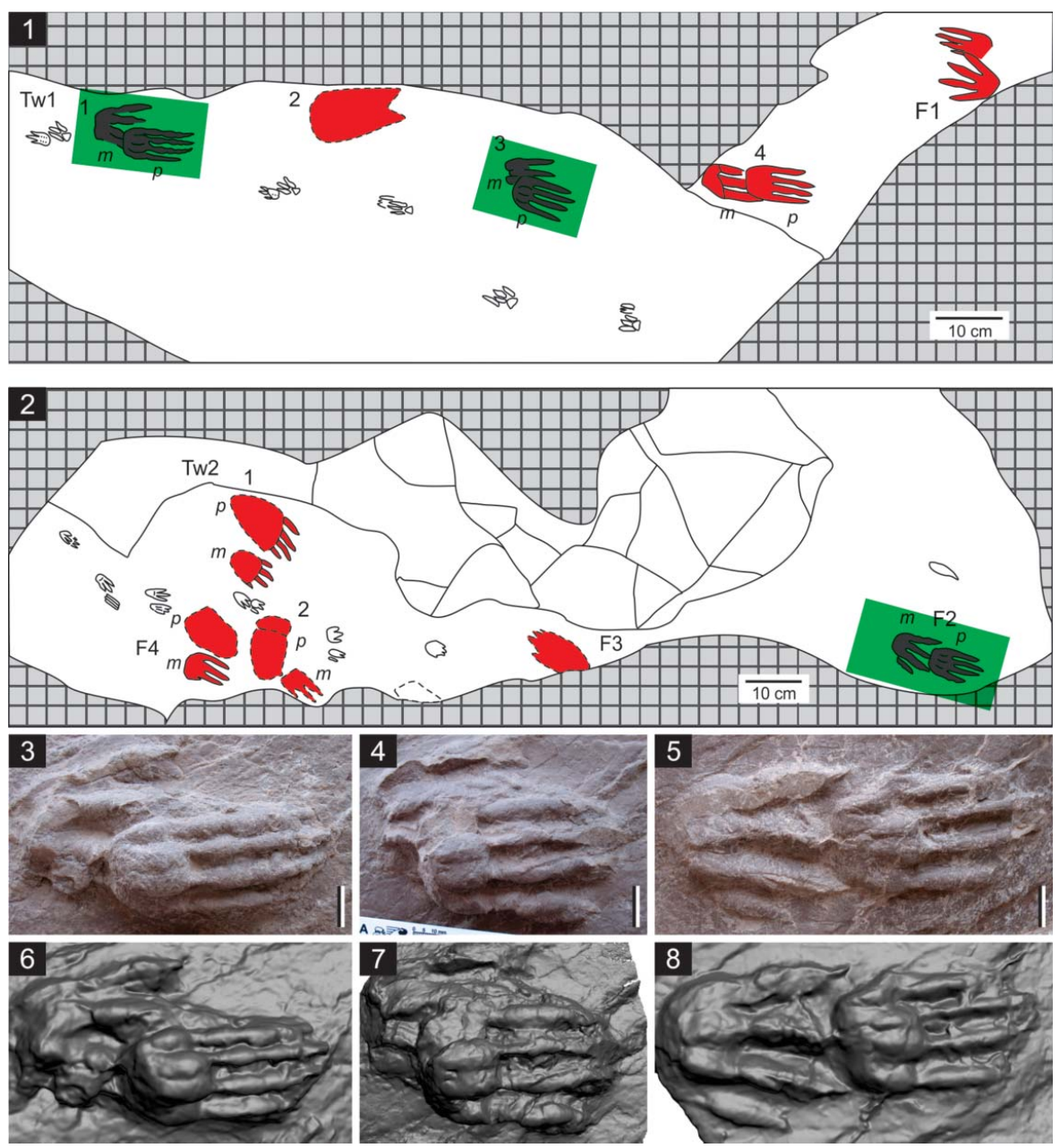

Figure 7. Drawing of the tracked surface (modified from Krapovickas and Nasif, 2011). 1. Upper area of the tracking surface. Scale bar is $10 \mathrm{~cm}$. 2. Lower area of the tracking surface. Scale bar is $10 \mathrm{~cm}$. 3-5. Manus-pes sets extracted from the tracking surface. 3 . Manus-pes set Tw1-1. Scale bar is $2 \mathrm{~cm}$. 4. Manus-pes set Tw1-3. Scale bar is $2 \mathrm{~cm}$. 5 . Manus-pes set F2. Scale bar is $2 \mathrm{~cm}$. 6-8. Captions of 3D models of the same Manus-pes sets. 6. Manus-pes set Tw1-1. 7. Manus-pes set Tw1-3. 8. Manus-pes set F2.

were generated through the ScanStudio software (version 2.0.2). These virtual models (Fig. 7, and 3D PDF in the supplementary figures S1, S2, and S3) easily allow us to observe three-dimensional features reinforcing morphological data provided by the new material studied as the asymmetrically arranged digit in manus impressions (see online Appendix S3) previously ignored.

\section{Systematic ichnology review}

Based on the new digital models and the numerous tracks and trackways recently recorded we are able to review the systematic ichnology of the ichnogenus.

Tracheria troyana (Krapovickas and Nasif, 2011)

1984 "Quiroteroides" (Cuerda et al., 1984, plate XV, figure 2 and plate XVI, figure 1).

1994 "tetradactylous mammal footprint" (Leonardi, 1994, plate XIX, figure 11).
2007 "huellas cuadrúpedas tetradáctilas" (Melchor et al., 2007, p. 54).

2009a "large tetradactyl rodent-like footprints" (Krapovickas et al., 2009a)

2009b "large tetradactyl rodent-like footprints" (Krapovickas et al., 2009b)

2010 “Botriodontipus isp.” (Melchor et al. 2010)

\section{Emended diagnosis}

Tetradactyl manus and pes impressions of sub-equal size, with long and robust digits with strong elongated claw marks. The manus footprints are asymmetrical. The digit III impression is the longest, while digits II and IV impressions are sub-equal and following in size, and finally digit $\mathrm{V}$ is the shortest and at times do not print. They present well developed phalangeal pads, but generally lacks metacarpal pads, resulting in an almost digitigrade impressions. In the pes imprints, the lateral digits 
(II-V) are shorter than central digits (III-IV), resulting in a symmetrical arrangement. Elongated phalangeal and metapodial pad impressions are present, occasionally printing two heel pads. Trackways are narrow with footprint impressions near to the midline, and pes impressions are placed in front of, and more lateral to the midline, than the manus impressions.

As it is a monospecific ichnogenus, the emended diagnosis is the same for both the ichnogenus and the ichnospecies.

\section{Comments}

The detailed footprint morphology and trackway patterns of T. troyana shown in A1 permit to assign numerous isolated footprints recorded in A2, B1, B2 to the ichnotaxa. Most of the tridactyl and tretradactyl footprints described in $\mathrm{A} 2, \mathrm{~B} 1$, and $\mathrm{B} 2$ can be assigned to either manus or pes imprints of $T$. troyana accordingly to the emended diagnosis of the ichnogenus (see Figs. 4 and 5). Manus imprints are regularly preserved as tridactyl footprints when the feet are not deeply impressed on the ground. This may be related to the sediment substrate consistency, as it is not plastic enough to record shallower morphological details (Allen, 1997). Also, some of the fossil footprints (Fig. 4.4) are preserved as undertracks, as evidenced by impression walls with gentle slopes and less morphological detail than true tracks generated in soft substrates, as was observed in laboratory experiments by Milàn and Bromley (2006).

\section{Discussion}

The new material of Tracheria troyana expands our knowledge of the ichnogenus because it demonstrates more detailed autopodium morphology than previously observable, and it allows the measurement and interpretation of gait patterns expressed in the new trackways. The new findings in the field, which preserve long trackways, allow the refinement of previous interpretations (Krapovickas and Nasif, 2011). The gait patterns observed are similar to the holotype trackway of $T$. troyana (see Krapovickas and Nasif, 2011), in which the pes impression is placed in front of the manus impression. According to Elbroch (2003) and De Angelo et al. (2008), the relative manus-pes step pattern, together with the regular positioning of the manus-pes sets to the sides of the midline (Fig. 4.1), is characteristic of an overstep walk gait. This gait commonly occurs in animals with relatively shorter limbs in relation to the trunk length (as muskrats, coatis, skunks, and porcupines) or in animals with relatively long limbs when compared to the short trunk length such as canids and felids (Elbroch, 2003; De Angelo et al., 2008). Such a gait involves the same-side half suspension of the body at the time the limbs move in the following sequence: left front foot, left hind foot, and after that, right front foot, right hind foot and the cycle of footfalls repeat (e.g. Elbroch, 2003).

The $T$. troyana producer seems to be more compatible with an overstep walk gait, relatively shorter limbs in relation to the trunk length, as it occurs in muskrats, coatis, skunks, and porcupines. The body proportions of the only extant dinomyid species, Dinomys branickii, also supports the interpretation of a short-limbed caviomorph (see Peters, 1873). The posture of the trackmaker, inferred from the preserved trackways, appears to be very similar to that of extant dinomyids, as previously discussed by Krapovickas and Nasif (2011). In modern dinomyids the hind foot is fully plantigrade and the front foot is plantigrade to almost digitigrade, only reaching the ground the metacarpal region of the feet but not completely (Peters, 1873).

T. troyana has been recorded in floodplain and interchannel area deposits, related to anastomosing and meandering fluvial systems. Other associated ichnospecies (including Macrauchenichnus rector, Macrauchenichnus isp., Gruipeda isp., small tridactyl rodentiform footprints, and large tridactyl footprints of rheiformes) also occur in playa lake and lake margin facies of this unit (Krapovickas, manuscript in preparation). In spite of possible preservational biases (e.g., poor visibility of $T$. troyana in sandstone deposits), the relative absence of $T$. troyana in other facies may indicate a tendency of the trace maker to inhabit areas next to perennial river systems with a fresh water table close to the sediment-air interface. Nevertheless, this hypothesis should be tested.

One of the objectives of this work was to contribute to protect the paleontological heritage from potential lost due to their prolonged exposure out of proper collection storage. We have generated digitized 3D copies of the holotype and paratype material of T. troyana so that further analyses can be made based on these 3D models. Such analyses may include taxonomic studies using geometric morphometrics, palaeobiological studies relating the area and other characteristics with the interpreted producer's body mass and mechanical studies of the foot/substrate interaction. The 3D materials are also available for education, and help to increase public awareness of the geosciences; they also foster geo-tourism to Vinchina, where the original material will be placed in the near future.

\section{Conclusions}

T. troyana represents a strongly distinctive ichnotaxa produced by an extinct large caviomorph of the endemic South American fauna. The newly recovered material 
permit to establish some of functional capabilities express in the trackways and allows to analyze in the future how this range compares to that of its living relatives. The reevaluation of T. troyana ichnotaxonomy is essential to properly document its morphology and later its preservational variants. The new well-preserved material allows us to recognize additional examples of $T$. troyana, suggesting that this ichnospecies is far more abundant in the Vinchina Formation than previously recognized. In addition, the common occurrence of $T$. troyana in the overbank facies of anastomosing and meandering fluvial systems may reflect a habitat preference the producer. Finally, the generation of $3 \mathrm{D}$ model of the holotype and paratype material of $T$. troyana facilitated the accurate documentation of material that is not yet properly curated.

\section{Acknowledgments}

We are grateful to C. O. Limarino, Y. Díaz, J. Schencman, H. Tassone, and P. Puerta for their collaboration during field work. We thank J. J. Scott for her comments that greatly improved the manuscript.

\section{Funding}

Funding for this research was provided by projects PICT 20112334, PICT 2014-1921 (V.K.), PICT 2012-727 (Limarino), and PICT 2014-1963 (S.M.).

\section{References}

Allen, J. R. L. 1997. Subfossil mammalian tracks (Flandrian) in the Severn Estuary, S.W. Britain: mechanics of formation, preservation and distribution. Philosophical Transactions of The Royal Society B Biological Sciences, 352: 481-518.

Amidon, W. H., Ciccioli, P. L., Marenssi, S. A., Limarino, C. O., Fisher, G. B., Burbank, D. W., and Kylander-Clark, A. 2016. $\mathrm{U}-\mathrm{Pb}$ ages of detrital and volcanic zircons of the Toro Negro Formation, northwestern Argentina: Age, provenance and sedimentation rates. Journal of South American Earth Sciences, 70: 237-250.

Angulo, R. J. and Casamiquela, R. M. 1982. Estudio estratigráfico de las unidades aflorantes en los acantilados de la costa norte del Golfo de San Matías (Río Negro y extremo austral de Buenos Aires) entre los meridianos $62^{\circ} 30^{\prime}$ y $64^{\circ}$ 30' W. Mundo Ameghiniano, 2: 20-86

Ciccioli, P., Marenssi, S. A., Rosello, E., and Limarino, C. O. 2013. Sedimentary patterns in the Vinchina Basin: Interplay between compressional and transcurrent tectonism during the Andean orogeny. Bollettino de Geofisica Teorica ed Applicata, 5(suppl. 2): 217-220.

Ciccioli, P. L., Limarino, C. O., Marenssi, S. A., Tedesco, A. M., and Tripaldi, A. 2010. Estratigrafía de la cuenca de vinchina (terciario), sierras pampeanas, provincia de la Rioja. Revista de la Asociación Geológica Argentina, 66: 146-155.
Ciccioli, P. L., Limarino, C. O., Marenssi, S. A., Tedesco, A. M., and Tripaldi, A. 2011. Tectosedimentary evolution of the La Troya and Vinchina depocenters (northern Bermejo Basin, Tertiary), La Rioja, Argentina. In Salfity, J., and Marquillas, R. A. (eds). Cenozoic Geology of the Central Andes of Argentina. SCS, Salta Argentina, 91-110.

Ciccioli, P. L., Limarino, C. O., Friedman, R., and Marenssi, S. A. 2014. New high precision U-Pb ages for the Vinchina Formation: Implications for the stratigraphy of the Bermejo Andean foreland basin (La Rioja province, western Argentina). Journal of South American Earth Sciences, 56: 200-213.

Cuerda, A. J., Cingolani, C. A., Varela, R., and Schauer, O. C. 1984. Descripción geológica de la Hoja 19d Mogna. Servicio Geológico Nacional, Boletín 192, Buenos Aires.

De Angelo, C., Paviolo, A., Di Blanco, Y., Di Bitetti, M., and Chiappe, A. 2008. Guía de huellas de los mamíferos de Misiones y otras áreas del subtrópico de Argentina. Ediciones del Subtrópico, Tucumán.

Elbroch, M. 2003. Mammal Tracks and Sign. A Guide to North American Species. Stackpole Books, Mechanicsburg, PA.

Frenguelli, J. 1950. Ichnites del Paleozoico Superior del oeste argentino. Revista de la Asociación Geológica Argentina, 5: 136-148.

Krapovickas, V., Mángano, M. G., and Marsicano, C. A. 2009a. Cenozoic tetrapod footprints from the Vinchina Basin, La Rioja, Argentina. Ameghiniana, Jornadas Argentinas de Paleontología de Vertebrados. San Rafael, Mendoza, 33 p.

Krapovickas, V., Mángano, M. G., and Marsicano, C. A. 2009b. Paleobiology of avian and mammalian fossil footprints from the south of South America. Journal of Vertebrate Paleontology, SVP 69th Annual Meeting, Bristol, 129 p.

Krapovickas, V. and Nasif, N. L. 2011. Large caviomorph rodent footprints of the late Oligocene Vinchina Formation, Argentina. Palaeontologia Electronica, 14(12A): 13 p.

Krapovickas, V., Toledo, N., and Muñoz, N. A. 2013. Huellas de perezosos (Xenarthra, Folivora) de la Formación Vinchina (Mioceno), provincia de la Rioja, Argentina. Ameghiniana, Reunión Anual de La Asociación Paleontológica Argentina. Cordoba, Argentina, 55-56.

Krapovickas, V. and Vizcaíno, S. F. 2016. The Cenozoic Radiation of Mammals. The South American example. In Mángano, M. G., and Buatois, L. A. (ed.). The TraceFossil Record of Major Evolutionary Events. SpringerVerlag, Germany, 371-410.

Leonardi, G. 1994. Annotated Atlas of South America Tetrapod Footprints (Devonian to Holocene) with an Appendix on Mexico and Central Americas. República Federativa do Brasil, Ministério de Minas e Energía, Secretaría de Minas e Metalurgía. Companhia de Pesquisa de Recursos Minerais, Brasília, Brazil.

Limarino, C., Tripaldi, A., Marenssi, S., Net, L., Re, G., and Caselli, A. 2001. Tectonic control on the evolution of the fluvial systems of the Vinchina Formation (Miocene), northwestern Argentina. Journal of South American Earth Sciences, 14: 751-762.

Marenssi, S. A., Net, L. I., Caselli, A., Tripaldi, A., and Limarino, C. O. 2000. Descripción e interpretación de discordancias intraformacionales en la Formación Vinchina (Neógeno), quebrada de La Troya, La Rioja, Argentina. Revista de la Asociación Geológica Argentina, 54: 414-418.

Marenssi, S. A., Ciccioli, P., Limarino, C. O., Schencman, J., and Diaz, Y. 2015. Using fluvial cyclicity to decipher the interaction of basement- and fold-thrust-belt tectonics in a broken 
foreland basin: Vinchina Formation (Miocene), northwestern Argentina. Journal of Sedimentary Research, 85: 361-380.

Melchor, R. N., Genise, J. F., and Visconti, G. 2007. Icnocenosis de vertebrados e invertebrados en facies fluviales meandrosas: la Formación Vinchina (Mioceno), La Rioja Argentina. Resúmenes, Quinta Reunión Argentina de Icnología y Tercera Reunión de Icnología del MERCOSUR. Argentina, 54 p.

Melchor, R. N., Genise, J. F., Farina, J. L., Sánchez, M. V., Sarzetti, L., and Visconti, G. 2010. Large striated burrows from fluvial deposits of the Neogene Vinchina Formation, La Rioja, Argentina: A crab origin suggested by neoichnology and sedimentology. Palaeogeography, Palaeoclimatology, Palaeoecology, 291: 400-418.

Miall, A. D. 1995. Whither stratigraphy? Sedimentary Geology, 100: 5-20.

Miall, A. D. 1996. The Geology of Fluvial Deposits. SpringerVerlag, Berlin Heidelberg, Germany.

Milàn, J. and Bromley, R. G. 2006. True tracks, undertracks and eroded tracks, experimental work with tetrapod tracks in laboratory and field. Palaeogeography, Palaeoclimatology, Palaeoecology, 231: 253-264.

Nasif, N. 2010. Los Dinomyidae (Rodentia, Caviomorpha) del Mioceno superior del noroeste argentino. Su anatomía cráneo-dentaria. Ph.D. thesis, Universidad Nacional de Tucumán, Argentina.

Peters, W. 1873. Ueber Dinomys, eine merkwürdige neue Gattung von Nagethieren aus Peru. Festschrift zur Feier des
Hundertjährigen Bestehens der Gesellschaft Naturforschender Freunde, 227-234.

Ramos, V. 1970. Estratigrafía y estructura del Terciario en la sierra de los Colorados (Provincia de La Rioja), República Argentina. Revista de la Asociación Geológica Argentina, 25: 359-382.

Romilio, A. and Salisbury, S. W. 2014. Large dinosaurian tracks from the Upper Cretaceous (Cenomanian-Turonian) portion of the Winton Formation, Lark Quarry, central-western Queensland, Australia: 3D photogrammetric analysis renders the "stampede trigger" scenario unlikely. Cretaceous Research, 51: 186-207.

Tripaldi, A., Net, L., Limarino, C., Marenssi, S., Re, G., and Caselli, A. 2001. Paleoambientes sedimentarios y procedencia de la Formación Vinchina, Mioceno, noroeste de la provincia de La Rioja. Revista de la Asociación Geológica Argentina, 56: 443-465.

Tripaldi, A. 2002. Análisis Sedimentológico de depósitos eólicos de Valles Intermontanos, su aplicación al estudio de secuencias terciarias del Noroeste Argentino. Ph.D. thesis, Universidad de Buenos Aires, Buenos Aires.

Turner, J. C. M. 1964. Descripción geológica de la hoja 15cVinchina (Provincia de La Rioja): carta geológico-económica de la República argentina, escala 1:200,000. Boletín de la Dirección Nacional de Geología y Minería, 100.

White, T. and Alberico, M. 1992. Dinomys branickii. Mammalian Species, 410: 1-5. 